\title{
The Effect of Macroeconomic Variables on Environment Quality during COVID-19 Pandemic
}

\author{
Rifda Nabila ${ }^{*}$, Qi Mangku Bahjatulloh ${ }^{1}$, Rosana Eri Puspita ${ }^{1}$, Arna Asna Annisa ${ }^{1}$, \\ Mohammad Rofiuddin ${ }^{1}$, and Saiful Anwar ${ }^{1}$ \\ ${ }^{1}$ Faculty of Islamic Economics and Business, IAIN Salatiga, Salatiga-Indonesia
}

\begin{abstract}
The global outbreak of coronavirus disease 2019 (COVID-19) affects every part of human life, including the physical world. The measures taken to control the spread of the virus have had a significant impact on slowing economic activity and the quality of the environment. This study discusses the macroeconomic variables on environmental quality during the pandemic. The purpose of this study is to examine the relationship between economic growth, human quality, poverty, and global trade on the quality of the environment in Indonesia. The data used a cross-sectional study for 34 provinces in Indonesia during 2020, while it analyzed the data using a multiple linear regression approach. The study results found that human quality has a positive effect on environmental quality in Indonesia, while the economic growth, poverty, and global trade variables have a negative effect. Novelty in this study examines the factors in the economy that affect the environment in the pandemic era.
\end{abstract}

\section{Introduction}

The COVID-19 pandemic that has hit the entire world for more than a year has impacted many things, one of which is the environmental aspect. Corona disease is the case that sparked the global outbreak [1-3] more lethal than SARS-Cov and MERS-CoV [4]. Indonesia reported 2 cases for the first time on March 2, 2020, and cases continue to increase to date [5]. Until May 28, 2021, the number of positive cases of COVID-19 was 1,803,361 cases, 1,654,557 cases recovered, and 50,100 cases died [6].

Apart from the negative aspects, this pandemic has a positive impact on the environment. The mobility of the people is minimal because of this virus. This has drastically reduced environmental pollution around the world, including in Indonesia. In addition, there was a marked reduction in pollution and greenhouse gas emissions [7]. This shows that COVID-19 has a positive contribution to environmental conservation efforts. The index used to describe the initial indication of seeing environmental conditions in a certain period is called the Environmental Quality Index (EQI) [8].

During a pandemic, governments in various countries continue to make efforts to provide complete information about the current outbreak and the impact that this outbreak has had.

\footnotetext{
* Corresponding author: rifdanabila@iainsalatiga.ac.id
} 
This is so that people can study the current situation and adjust their life activities, including economic activities [9].

The collapse of the economy due to the impact of the pandemic is inevitable. The pandemic succeeded in paralyzing even the most resilient markets, threatening national economic growth and the global economy [10]. Some indicators show that the COVID-19 outbreak can cause damage to the global economy [11]. This damage to the global economy is mainly due to uncertainty and reduced mobility of people and goods [12-13], which may be greater than the recession that occurred during the 2008 financial crisis [14].

Economic growth, indicated by the magnitude of the increase in actual output (real GDP), tends to impose costs on the environment. These impacts include the use of non-renewable resources, increased pollution, loss of environmental habitat, and the occurrence of global warming [15]. It is a considerable challenge to mediate in the interests of economic growth and environmental quality. This becomes interesting and very important when connecting environmental problems with development because it includes the welfare of all generations [16].

Many studies support the view that increasing a country's economic growth affects the quality of the environment positively. This shows that, when looking at the effects of growth and trade on the environment, one cannot simply link an increase in a country's economic activity with an increase in environmental damage that occurs in that country. [17]. The results of other studies show different results. The negative impact of economic activity causes water pollution, air pollution, and others [18-20].

Another environmental and economic problem is poverty. Dasgupta's research states a positive relationship between the poor in the village and environmental degradation [21]. Some studies show conflicting results. Poor people do not have sufficient resources to destroy the surrounding environment. This is because the poor still rely on products from nature so that they will protect nature as much as possible so that they met their needs [20].

Evaluation of regional and environmental development also needs to be planned immediately. It related this to the macroeconomic outcome aspects of a region. This can be seen from the area's Human Development Index (HDI) [22]. Currently, the government tends to be separate when it comes to intervening in the HDI and environmental aspects [23]. Several empirical studies show the relationship between HDI and environmental quality [20, $22,24-25]$. Increasing the quality of humans will have an impact on increasing economic activity on a large scale. This can lead to increased environmental damage as resources are overexploited, and industrialization is carried out in an unsustainable system [17]. Different things reveal that there is no direct relationship between HDI and environmental quality [26].

The purpose of this study is to examine the relationship between economic growth, human quality, poverty, and global trade on the quality of the environment in Indonesia during the pandemic.

\section{Research Method}

This study uses cross-section data. Cross-section data (between individuals/spaces) is collected at a specific time and describes conditions that occur at this time, such as data on companies, regions, and others. [27]. The data used are secondary data from 34 provinces in Indonesia during 2020. The purpose of this study is to determine the relationship between the Gross Domestic Regional Product (GDRP), Human Development Index (HDI), and Poverty (POV) on the Environmental Quality Index (EQI). This study uses a multiple regression model with the following regression equation:

$$
E Q I=\alpha+\beta_{1} G D R P+\beta_{2} P O V+\beta_{3} H D I+e i
$$


Catatan:

EQI : Environmental Quality Index

GRDP : Gross Regional Domestic Product

POV : Poverty

HDI : Human Development Index

$\alpha:$ Intercept or constant

$\beta$ : coefficient or slope

$e:$ error term

Environmental Quality Index (EQI) data is taken from the Ministry of Environment and Forestry, while Human Development Index (HDI), Gross Regional Domestic Product (GDRP), and Poverty (POV) data are taken from data from the Indonesia Statistics (BPS).

Environmental Quality Index (EQI) is an indicator of environmental management performance nationally that can be used as information to support the policy-making process related to environmental protection and management [28]. The Environmental Quality Index does not merely provide a ranking of the quality of the environment but is also an indication of efforts to improve the quality of the environment in provincial and national areas [29]. The data is in the form of percent of the Air Quality Index, Air Quality Index, and Land Cover Quality Index.

Gross Regional Domestic Product (GDRP) is the amount of added value generated by all business units in a specific area/is the total value of final goods and services produced by all economic units of a region. The GDRP data used is the GDRB at constant prices, which shows the added value of goods and services calculated using the prevailing prices in a specific year as the base year. GDRP at constant prices is used to determine real economic growth from year to year [30]. Data in the form of a percentage.

Poverty is an economic inability to meet basic food and non-food needs as measured in terms of expenditure. So the population is said to be poor if they have an average monthly expenditure per capita below the poverty line [31]. The data is in the form of percent of poor people by province.

The Human Development Index (HDI) explains how people can access the results of development to get income, education, health, and others. The three basic dimensions of HDI are longevity and healthy life, knowledge, and a decent standard of living. HDI is an essential indicator in measuring the success of developing the quality of human life [32]. Data is in the form of percent of health, education, and expenditure levels.

\section{Result and Discussions}

\section{1 Descriptive Statistics}

The results of descriptive statistics for each variable can be seen in Table 1 . The number of valid observations was 34, consisting of 34 provinces in Indonesia.

Table 1. Descriptive Statistics (\%).

\begin{tabular}{|l|c|c|c|c|}
\hline \multicolumn{1}{|c|}{ Variables } & Mean & Min & Max & Std Dev. \\
\hline $\begin{array}{l}\text { Environmental } \\
\text { Quality Index }\end{array}$ & 71.0235 & 52.9800 & 79.7500 & 5.6087 \\
\hline $\begin{array}{l}\text { Human Development } \\
\text { Index }\end{array}$ & 71.0808 & 60.4400 & 80.7700 & 3.9019 \\
\hline $\begin{array}{l}\text { Gross Regional } \\
\text { Domestic Product }\end{array}$ & -1.2520 & -9.3100 & 4.9200 & 2.3711 \\
\hline Poverty & 10.8056 & 4.4500 & 26.8000 & 5.4130 \\
\hline
\end{tabular}




\section{2 Result and Discussion}

The results of the research model estimation can be seen in Table 2 .

Table 2. Hasil Estimasi Model Penelitian

\begin{tabular}{|c|c|c|c|c|}
\hline Variables & Coefficient & Std. Error & t-Statistic & Probability \\
\hline C & 116.3771 & 22.35066 & 5.206877 & 0.0000 \\
\hline GDRP & 0.275230 & 0.406833 & 0.676518 & 0.5039 \\
\hline POV & 0.092633 & 0.204219 & 0.453596 & 0.6534 \\
\hline HDI & -0.647290 & 0.297658 & -2.174610 & 0.0377 \\
\hline
\end{tabular}

Based on the estimation results in table 2, the empirical model in the study is obtained as follows:

$$
E Q I=116.3771+0.275230 G D R P+0.092633 P O V-0.647290 H D I
$$

It can be seen that HDI has a relationship with EQI, with a negative coefficient. This means that when the quality of human resources increases, the quality of the environment will decrease. This shows that Indonesia, a developing country, is in the early stages of development. This makes people tend to have a higher consumptive lifestyle. This consumptive lifestyle requires people to carry out more diverse and complex business activities. This impacts increasing global warming, eventually climate change, and affects the quality of the environment. Empirically this study is by previous research, which states that there is a relationship between HDI and EQI [20, 22, 24-25].

In this study, the relationship between GDRP and EQI shows that these two variables do not affect. This shows that in a pandemic condition like now, the increase or decrease in environmental quality in each region is not determined by the region's economic condition. The lockdown policy implemented during a pandemic like this dramatically reduces human mobility and does not significantly impact the quality of the existing environment. This result is different from previous research, which shows that higher human mobility can improve the quality of the environment around it [17-19,33]. This means that the number of activities carried out by humans, including increasing economic activities, can impact environmental quality.

The results of the exact correlation also occur for the variables of poverty and environmental quality. This study shows that there is no significant relationship between poverty and environmental quality. This contradicts many previous studies. This is due to different research conditions. The poor have a high dependence on natural resources to survive. In normal conditions, the poor will try to take as much from nature as possible to make ends meet. This causes the environmental quality to deteriorate. Different things happened during the COVID-19 pandemic. The existence of a pandemic, forcing people to reduce their mobility outside the home. This means that the poor cannot exploit natural resources and the environment. This result contradicts empirical studies which explain that there is a relationship between poverty and environmental quality, both positive and negative [20-21]. 


\section{Conclusion}

The findings of this study indicate that the quality of Human Resources harms environmental quality. This shows that human development has an impact on environmental quality degradation. On the other hand, the level of GRDP and poverty do not significantly affect the quality of the environment in Indonesia. Based on these findings, the government is advised to realize economic competitiveness based on natural resources and renewable energy by using environmentally friendly based technology based on these findings.

\section{Acknowledgements}

The author is very grateful to the FEBI IAIN Salatiga lecturers who have helped a lot in providing suggestions to improve this article. In addition, the authors also thank the employees of the Ministry of Environment and Forestry of the Republic of Indonesia who has helped provide data and provide input for this article. The authors also appreciate the editor's efforts and critical comments provided by anonymous reviewers.

\section{References}

1. J. T. Wu, K. Leung, and G. M. Leung, "Nowcasting and forecasting the potential domestic and international spread of the 2019-nCoV outbreak originating in Wuhan, China: a modelling study," Lancet, vol. 395, no. 10225, pp. 689-697, doi: https://doi.org/10.1016/S0140-6736(20)30260-9 (2020)

2. J. T. Wu et al., "Estimating clinical severity of COVID-19 from the transmission dynamics in Wuhan, China," Nat. Med., vol. 26, no. 4, pp. 506-510, doi: 10.1038/s41591-020-0822-7 (2020)

3. M. K. Mostafa, G. Gamal, and A. Wafiq, "The impact of COVID 19 on air pollution levels and other environmental indicators - A case study of Egypt," J. Environ. Manage., vol. 277, p. 111496, 2021, doi: 10.1016/j.jenvman.2020.111496 (October 2020)

4. S. A. Meo et al., "Novel coronavirus 2019-nCoV: Prevalence, biological and clinical characteristics comparison with SARS-CoV and MERS-CoV," Eur. Rev. Med. Pharmacol.Sci., vol. 24, no. 4, pp. 2012-2019, doi: 10.26355/eurrev_202002_20379 (2020)

5. Kementrian Keuangan Republik Indonesia, "Menjaga Ekonomi Indonesia Terhadap Dampak Negatif Pandemik COVID-19," Kementrian Keuangan Republik Indonesia. https://www.kemenkeu.go.id/publikasi/siaran-pers/siaran-pers-menjaga-ekonomiindonesia-terhadap-dampak-negatif-pandemik-covid-19/ (2020)

6. Komite Penanganan COVID-19 Dan Pemulihan Ekonomi Nasional, "Data Sebaran COVID di Indonesia," Komite Penanganan COVID-19 Dan Pemulihan Ekonomi Nasional. https://covid19.go.id/ (2021)

7. I. Khan, D. Shah, and S. S. Shah, "COVID-19 pandemic and its positive impacts on environment: an updated review," Int. J. Environ. Sci. Technol., vol. 18, no. 2, pp. 521-530, 2021, doi: 10.1007/s13762-020-03021-3.

8. A. M. M. Lobdell, D., J. Jagai, L. Messer, K. Rappazzo, K. Messier, G. Smith, S. Pierson, B. Rosenbaum, "Environmental Quality Index - Overview Report (20002005) (Final, 2014)," Washington, (2014)

9. Y. Song, Z. Li, J. Liu, T. Yang, M. Zhang, and J. Pang, "The effect of environmental 
regulation on air quality in China: A natural experiment during the COVID-19 pandemic," Atmos. Pollut. Res., vol. 12, no. 4, pp. 21-30, doi: 10.1016/j.apr.2021.02.010 (2021)

10. R. Sharetta, "The economic impact of COVID-19," Nuffield Departement of Medicine: CENTER FOR TROPICAL MEDECINE AND GLOBAL HEALTH. https://www.tropicalmedicine.ox.ac.uk/news/the-economic-impact-of-covid-19 (2020)

11. V. Kumar, S. B. Singh, and S. Singh, "COVID-19: Environment concern and impact of Indian medicinal system,” J. Environ. Chem. Eng., vol. 8, no. 5, p. 104144, doi: https://doi.org/10.1016/j.jece.2020.104144 (2020)

12. W. McKibbin and R. Fernando, "The Global Macroeconomic Impacts of COVID19: Seven Scenarios," Asian Econ. Pap., vol. 20, no. 2, pp. 1-30, doi: 10.1162/asep_a_00796 (May 2021)

13. N. Fernandes, "Economic effects of coronavirus outbreak ( COVID-19) on the world economy Nuno Fernandes Full Professor of Finance IESE Business School Spain," SSRN Electron. Journal, ISSN 1556-5068, Elsevier BV, pp. 0-29, (2020)

14. Q. Wang and M. Su, "A preliminary assessment of the impact of COVID-19 on environment - A case study of China," Sci. Total Environ., vol. 728, p. 138915, doi: https://doi.org/10.1016/j.scitotenv.2020.138915 (2020)

15. T. Pettinger, "Environmental Impact of Economic Growth," Economics help, 2021. https://www.economicshelp.org/blog/145989/economics/environmental-impact-ofeconomic-growth/ (2021)

16. S. Oktavilia, F. X. Sugiyanto, A. Pujiati, and A. Setyadharma, "Effect of Energy Consumption and Economic Growth towards the environmental quality of Indonesia," vol. 7, no. 201 9, pp. 7-10, (2019)

17. B. R. Copeland and M. S. Taylor, "Trade, growth, and the environment," J. Econ. Lit., vol. 42, no. 1, pp. 7-71, doi: 10.1257/.42.1.7 (2004)

18. I. R. Ridwan, "DAMPAK INDUSTRI TERHADAP LINGKUNGAN DAN SOSIAL," GEA, J. Pendidik. Geogr., vol. 7, (2007)

19. M. Rofiuddin, S. Aisyah, D. N. Pratiwi, A. A. Annisa, R. E. Puspita, and R. Nabila, "Does Economic Growth Reduce Pollution? Empirical Evidence from Low Income Countries," E3S Web Conf., vol. 125, no. 201 9, pp. 15-18, doi: 10.1051/e3sconf/201912506002. (2019)

20. O. Shanty, W. P. Dita, Firmansyah, and F. X. Sugiyanto, "The Relationship between Environmental Degradation, Poverty and Human Quality in Indonesia," E3S Web Conf., vol. 73, pp. 4-6, 2018, doi: 10.1051/e3sconf/20187310020.(2018)

21. P. Dusgupta, C. Folke, and K. G. Maler, The Environmental Resource Base and Human Welfare. Stockholm: Beijer Repraint Series, (1994)

22. A. S. Pambudi, "Analisis Keterkaitan Indeks Pembangunan Hidup Di Sulawesi Selatan Analysis of the Relationship Between Human Development Index Toward Environmental Quality Index in South Sulawesi," J. Inov. Apar., vol. 2, no. 1, pp. 109-123, (2020)

23. I. Ummi, Rusdarti, and H. Yanto, "Relationship of the GRDP Sectors with Environmental Quality Index in Indonesia 2012-2017," J. Econ. Educ., vol. 8, no. 2, pp. 152-158, (2019)

24. V. Costantini and S. Monni, "Measuring human and sustainable development: An integrated approach for European countries," no. May 2014, pp. 1-35, 2004, [Online].Available:

http://search.ebscohost.com/login.aspx?direct=true \&db=eoh\&AN=1141444\&site=e host-live\%0Ahttp://www.dipeco.uniroma3.it/public/pdf/WP41.pdf (2004)

25. A. Rahajeng, "Pertumbuhan Ekonomi dan Kualitas Lingkungan Hidup Indonesia 
2014: Modifikasi Kurva Kutznet,” Pros. Semin. Nas. Teknol. Terap. SV UGM(2014)

26. E. Neumayer, "The human development index and sustainability - A constructive proposal," Ecol. Econ., vol. 39, no. 1, pp. 101-114, doi: 10.1016/S09218009(01)00201-4 (2001)

27. J. Suteja, U. Pasundan, A. Gunardi, and U. Pasundan, "EViews Dalam Riset Keuangan," no. June, (2020)

28. K. L. H. dan Kehutanan, "Indeks Kualitas Lingkungan Hidup,” (2019)

29. Kementrian Lingkungan Hidup dan Kehutanan, "Laporan Kinerja, Adaptasi di tengah Pandemic Mengawal Jaman Berubah,” (2020)

30. Badan Pusat Statistik, "Produk Domestik Regional Bruto," Badan Pusat Statistik, https://www.bps.go.id/indicator/52/291/1/-seri-2010-laju-pertumbuhan-produkdomestik-regional-bruto-atas-dasar-harga-konstan-2010-menurut-provinsi.html (2021)

31. Badan Pusat Statistik, "Kemiskinan," Badan Pusat Statistik, 2021. https://www.bps.go.id/subject/23/kemiskinan-danketimpangan.html\#subjekViewTab1 (2021)

32. Badan Pusat Statistik, "Indeks Pembangunan Manusia," Badan Pusat Statistik, https://www.bps.go.id/subject/26/indeks-pembangunan manusia.html\#subjekViewTab1.html (2020)

33. R. Bao and A. Zhang, "Does lockdown reduce air pollution? Evidence from 44 cities in northern China," Sci. Total Environ., vol. 731, p. 139052, doi: https://doi.org/10.1016/j.scitotenv.2020.139052 (2020) 